\title{
Natural Resources as Agents of Economic Emergence: Evidence from Cameroon
}

\section{${ }^{1}$ NJIMATED, Godfrey Forgha, ${ }^{2}$ YAKUM, Ivan Mboambogoh}

${ }^{1}$ Professor of Economics, Deputy Director, HITL, University of Bamenda

(Email: unicalub@yahoo.com, Tel: +237 677924471)

${ }^{2}$ Faculty of Economics and Management Sciences, University of Bamenda

(Email: ivanyakum@yahoo.com, Tel: +237 675855575)

\begin{abstract}
Classical economists were of the view that development is a convoluted process and as such countries can only achieve development through a linear path consisting of five stages. Going by this philosophy, the country under the New Deal Government of Cameroon, by its status is between the traditional stage (stage 1) and the pre-conditions to take-off stage (stage 2). Admitting all efforts are put in place as drivers for take-off stage (emergence or stage 3), it becomes imperative to evaluate the sustainability of this economic emergence. Thus, sustainability drivers such as real gross domestic product per capita, availability of quality agricultural land, energy supply, population growth, enrolment into higher education, foreign direct investments and gross domestic capital formation are evaluated to account for the feasibility of Cameroon's emergence comes 2035. Based on time series data from 1960 to 2017 inclusive on the above listed variables, and using the Structural Vector-Auto Regressive (SVAR) models, the findings yield some useful policy guides. Subject to pre and post-tests of estimation, forecasting was guaranteed up to 58years outside the data set. With a justified 70.2 percent simulation results, the findings reveal that total natural resources rents can actually pave the way for sustainable growth and development in Cameroon by 2035 and beyond. The true direction therefore reveals that, in addition to proper management of the available total natural resource rents, reasonable portion of government expenditure and returns on foreign direct investment should be directed to agricultural research, investment in education especially in science, and technology, engineering and mathematics (STEM) and innovation, rents conservation, infrastructural development, energy supply, population growth and the trade-off of leisure in favour of work. These among others are the gate-ways for sustainable growth, development and hence the emergence of Cameroon in 2035.
\end{abstract}

Key Words: Natural Resources; Rents; Economic Emergence; Real Gross Product Per Capital; Energy Supply; Agricultural Land; Foreign Direct Investment; Gross Domestic Capital Formation and Sustainable Development.

Received: $12 / 0912019$
Accepted: 19/11/2019
DOI: https//dx.doi.org/10.4314/jcas.v15i2.3
C The Authors. This work is licensed under the Creative Commons Attribution 4.0 International Licence. 


\section{Résumés}

Les économistes classiques estimaient que le développement était un processus complexe et que, pour les pays sous développé, le développement ne pouvait se réaliser que par une voie linéaire de cinq étapes. Fidèle à cette philosophie, le pays sous le gouvernement du New Deal du Cameroun se situe par son statut entre la phase traditionnelle (phase 1) et les conditions préalables au décollage (phase 2). En admettant que tous les efforts sont mis en place en tant que moteurs de la phase du décollage (émergence ou phase 3), il devient impératif d'évaluer la durabilité de cette émergence économique. Ainsi, les facteurs de durabilité tels que le produit intérieur brut réel par habitant, la disponibilité de terres agricoles de qualité, l'approvisionnement en énergie, la croissance démographique, l'inscription au nouveau d'étude supérieur, les investissements directs étrangers et la formation de capital intérieur brut sont évalués pour rendre compte de la faisabilité de l'émergence du Cameroun à l'horizon 2035 sur la base des données chronologiques de 1960 à 2017 inclusivement sur les variables énumérées ci-dessus, et à l'aide des modèles SVAR (Structural Vector-Auto Regressive), les résultats obtenus fournissent des indications utiles sur les politiques à suivre. Sous réserve de tests préalables et postérieurs aux estimations, les prévisions étaient garanties jusqu'à 58 ans en dehors de l'ensemble des données. Avec des résultats de simulation justifiés à $70,2 \%$, les résultats montrent que la totalité des loyer tirés des ressources naturelles peuvent réellement ouvrir la voie à une croissance et à un développement durables au Cameroun à l'horizon 2035 et au-delà. La véritable orientation révèle donc que, en-plus de la gestion appropriée des loyers totaux disponibles pour les ressources naturelles, une partie raisonnable des dépenses publiques et des revenus des investissements étrangers directs devrait être consacrée à la recherche agricole, aux investissements dans l'éducation, en particulier dans les domaines de la science et de la technologie, de l'ingénierie et des mathématiques (STEM) et innovation, la conservation des loyers, le développement des infrastructures, l'offre énergétique, la croissance démographique et la compromission des loisirs en faveur du travail. Celles-ci, entre autres, sont les portes d'entrée pour une croissance durable, le développement et donc l'émergence du Cameroun en 2035.

Mots clés : Ressources naturelles; Les loyers; Émergence économique; Produit brut réel par capital; Réserve d'énergie; Terre agricole; L'investissement étranger direct; Formation de capital intérieur brut et développement durable. 


\section{Introduction}

The relevance of natural resources endowment in world development in general and developing countries in particular cannot be overemphasized. This explains why occupants of the natural resource endowed areas depend on around the exploitation and the utilization of these resources in agriculture, mining, industrialization, extraction and manufacturing. These resources have contributed significantly both positively and negatively to the economic growth and development of these economies. Within the domain of natural resources led economic growth, Adam Smith (1776)in his famous view on sustainable economic growth and development required that proper investigation should be made into the nature and the bases of which the wealth of nations are generated. According to him, the nature of any economy depends on the level of its natural resource use. Those with negative effect see it as a "curse" rather than a "blessing" on economic growth and development. Gylfason (2001) observes that natural capital crowds out other forms of capital among which are human, institutional, physical, and foreign.

The economic depression and other limiting activities associated with external resources made their contribution to the economies of third world countries especially those of Africa to decline over time. In fact, many Less Developed Countries (LDCs) that have high reliance on exporting small sets of commodities have suffered from large swings in revenues owing to unstable prices of these commodities in the world markets which have also pruned domestic economic earnings. Furthermore, the reliance on external resources has drastically dropped in favour of natural resources in most of the LDCs. With this, it is observed that foreign resources have helped, but could not deliver and sustained the economic emergence of some of the countries in Africa and beyond. The unanswered question then is, can it be possible for such countries to sustain their emergence (NEPAD, 2013)? While some views are for, others claim that higher energy prices, inadequate quality land, inadequate investment on education, inadequate women empowerment, poor innovation and bad governance account for the deficiencies(NEPAD, 2013).

To address the problem of high energy prices and the OPEC oil embargo during the 1970's, economists in the world have systematically examined the growth effects of non-renewable natural resources within the ambits of the dynamic general macroeconomic equilibrium models using an exogenous-growth framework developed by Solow (1974) and Stiglitz (1974). Their findings show that sustained economic growth is possible as long as the reproducible factor of production (physical capital) can be substituted for exhaustible natural resources along the economy's balanced growth path. In this direction, the quantity of utilized natural resources per unit of GDP has to steadily decline in such country. Also, African Heads of State and Governments in 2011 stressed the need to transform their existing political will on non-renewable natural resources into concrete policy responses and actions. This has accounted for an increase in revenue generated from the natural resources such as rents and royalties. For instance, royalties and licenses generated in Africa have continuously increased from about 1.6-2.8 billion USD for the years 2005 and 2011 respectively (ADI, 2014). This trend is observed to be on the rise since 2011 and have been projected to be more than triple its 2011 value by 2020 .

In spite of the rising trend presented above, the economic growth rate of the African continent has been fluctuating in response to the changing choices of resources and their preferences, which are in line with the fluctuation in their economic circumstances. In that light it can be observed that, the GDP of the continent has been fluctuating: 
$4.45 \%$ in $1980,2.82 \%$ in $1985,2.26 \%$ in 1990 , $3.06 \% 1995,3.69 \%$ in $2000,5.30 \%$ for 2005 before dropping to $4.74 \%$ in the year 2010 (ADI, 2014). The situation is not different in Cameroon since her annual GDP growth rate stood at $4.13 \%$, $4.17 \%, 2.3 \%$ and $3.27 \%$ for the years 1995, 2000, 2005 and 2010 respectively (WDI, 2014). This is a country called Africa in miniature because of its rich natural resources. The "curse of natural resources" is a well-known phenomenon since the seminal work of Sachs and Warner (1995) in which they provided evidence that natural resource-rich countries have lower economic growth rates than their natural resource-poor counterparts. Case studies and historical examples tend also to confirm the negative impact of natural resource abundance on economic performances (Njimanted et al, 2015).

In accordance with the above, while studies such as those of De Melo et al (1997), Branns Chweiler (2009), Wujung and Fozoh (2016) indicate the existence of positive influence of natural resources on economic growth and development, those of Njimanted and Nkwetta (2015), Alexeev and Conrad (2010) among others show insignificant or negative influence of natural resource abundance on economic growth and development. As the debate continues, most of these studies have either employed Ordinary Least Squares (OLS) technique, descriptive statistics or other non-influential techniques to arrive at their value judgments. In most cases they have utilized cross-sectional data or panel data where the conditionality associated with their usage are neglected. Very few of such studies have employed the use of the dynamic of time series data in developing economy and have used, the sample size " $n$ " of less than 30 which is insufficient for valid statistical analyses. None of these studies especially on economic emergence has been conducted in Cameroon and where conducted, Cameroon is used as a data point. Therefore, this study aims at investigating into the extent to which natural resources rents and the dynamics of its drivers are capable of sustaining the anticipated economic emergence of Cameroon by 2035 using the Structural Vector Auto-regressive methodology over the period of 58 years. The finding from this study will also be used for policy simulation beyond 2035 .

Based on the above, the rest of this work is anchored on literature review in section two, analytical methodology in section three, presentation and discussion of findings in section four and the study will be drawn to logical conclusion in section five.

\section{Literature Review}

An important number of both theoretical and empirical studies have tried to investigate the nexus between natural resources availability and economic emergence. De Melo et al., (1997), conducted a study on the impact of natural resources availability on economic growth. They found that the impact of natural resources on economic growth is not clear. Weak positive growth effects seem to appear but, among the cluster of initial conditions, it is difficult to identify precisely the impact of natural resources on economic growth.

Brunnschweiler (2009) studies the impact of oil on economic development in the transition economies over the 1990-2006 period. She uses oil production and oil reserves to measure natural resource abundance since these data are less subject to other factors (climate, price fluctuations) than oil production. With data generated from British Petrol (BP) database and the US Energy Information Agency, it was revealed that oil (production/reserves) has a strong positive influence on economic growth and this influence is robust whatever the specification of the model is. Changing the measure of oil abundance (exports per capita, exports/ 
merchandise exports, exports/GDP) did not modify the main result.

Brunnschweiler (2009) also studied the issue of oil ownership, by considering four main ownership structures: state ownership with and without control, private domestic ownership and private foreign ownership. Based on the thinking that ownership structure influences institutional outcomes especially fiscal regime (Luong and Weinthal, 2001, 2009), the estimate suggests that the state ownership with control has higher growth effects than the three other ownership structures. This result contradicts Luong and Weinthal's thesis that considers state ownership as the worst ownership structure since it does not generate incentives for investing in an efficient and stable fiscal system.

Alexeev and Conrad (2010) provide a study in which they examine the impact of natural resource endowment (oil wealth) on economic growth, on institutions and on welfare (infant mortality, life expectancy at birth, etc). They use cross-country regressions and introduce a dummy variable that equals 1 if the country is in transition and zero for otherwise. Their main results indicate that natural resources do not seem to have affected economic growth between 1996 and 2005. They find some evidence that natural resource abundance is associated with higher infant mortality in transition economies but, compared to other economies in transition, resource-rich transition economies do not perform worse.

Njimanted and Nkwetta (2015) conducted a study on the impact of timber export on economic growth in Cameroon over 34 years (1980 to 2014 inclusive), with data collected from the Food and Agricultural Organization and World Development Indicators, and based on the Johansen Co integration and Error Correction Modeling; the results showed that timber export has an insignificant effect on the economic growth of Cameroon in the short run and in the long run it has a significant positive effect.

Wujung and Fozoh (2016) carried out a study on the effect of mobilizing various sources of domestic resources on the economic growth of Cameroon. The empirical investigation carried out using data from the World Bank's development indicators (WDI, 2014) for Cameroon within the period 1980- 2013, and based on descriptive statistics and the Instrumental Variable Generalized Method of Moments (IVGMM) used to analyze the data, the results show that there is a positive and significant relationship between the various sources of domestic resources and economic growth in Cameroon.

The theoretical underpinning of this paper is drawn from the Solow (1974) model. The model states that sustained economic growth is possible so long as the reproducible factor of production (physical capital) can be substituted for exhaustible natural resources along the economy's balanced growth path. The accumulation of capital is at the center of the economy in this model. The Neo-Classical Solow model is from the ClassicalKeynesian model whose principal actors are Samuelson, James Tobin, Hicks and Hansen.

The fundamental assumptions on which this model rely on are that countries produce and consume homogenous goods, production is done in a situation of perfect competition, technology is exogenous, technology can be presented by a production function of the Neo-Classical type based on the substitutable factors (capital and labour), the global consumption is presented by a Keynesian function, the rate of participation in the employment of the population is constant. Based on the assumptions presented above, the output function is therefore continuous, admitting the first partial derivative and there is no possibility of production without capital. To draw the condition for equilibrium growth from this model, we consider that in the function $y_{t}=f\left(k_{t}\right)$, the 
expression $\frac{d k_{t}}{k_{t} d t}$ represents the per capita growth rate where $k=\frac{K}{L}$ and thus:

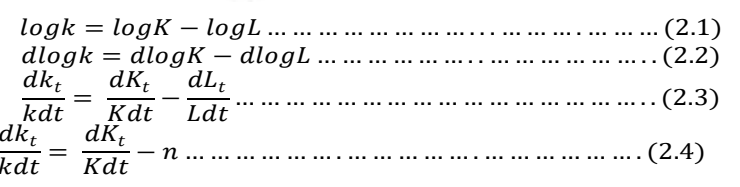

Wherein, $\mathrm{n}$ is the natural growth rate or the demographic growth rate. The main aim here is to search for an equilibrium economic growth. This can be demonstrated as follows;

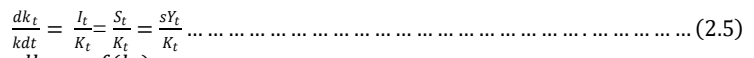

$\frac{d k_{t}}{K_{t} d t}=\frac{s f\left(k_{t}\right)}{k_{t}}-n$

$\frac{d k_{t}}{d t}=s f\left(k_{t}\right)-n k_{t}$

Equation (2.7) is the fundamental equation of the Solow growth model which explains that, for there to be equilibrium economic growth, it suffices that $\frac{d k_{t}}{d t}=0$. Thus the economy will be at equilibrium if $s f\left(k_{t}\right)=n k_{t}$. This equilibrium relation indicates that sustained economic growth is possible so long as the reproducible factor of production (physical capital) can be substituted for exhaustible natural resources along the economy's balanced growth path $\left(s f\left(k_{t}\right)=n k_{t}\right)$. The guaranteed growth rate will therefore be equal to the natural growth rate in the economy.

The weakness of the above model that limits its widespread applicability is based on the theoretical unrealistic assumptions of the model. The assumptions are unrealistic to be attained in any economy. Nonetheless, the general framework of the above model shows that when the two forces $\left(s f\left(k_{t}\right)\right.$ and $\left.n k_{t}\right)$ equilibrate, the income per head in the economy will be constant and the economy will be in a dynamic equilibrium. Another theoretical foundation of this paper is the Harrod-Domar growth model (Harrod, 1939; and Domar, 1946) is a conventional tool that throws light on the economic growth rate derived from the productivity of capital and the savings level. According to the Harrod-Domar growth model, the growth rate of an economy is dependent on two important factors: the national savings level and the incremental capital-output ratio of the economy. This model is based on the assumptions that investment is equal to savings; the economy is making full use of capital stock; the economy is at full employment; there is no government intervention (the economy is closed) and no depreciation, the model holds that the rate of growth in GDP will be sustainable if the growth rate of capital stock and labour is the same as income growth rate (warranted rate of growth). The framework (not presented due to space) laid emphasis on three growth rates, namely, the effective growth rate $(\mathrm{g})$ which is the rate of economic growth actually realized in an economy in a given time period, the guaranteed growth rate $\left(g_{w}\right)$ which is the rate of growth that ensures equilibrium between savings and investment and the natural growth rate $\left(g_{n}\right)$ which is the full employment growth rate.

This paper lays emphasis on the natural growth rate $\left(g_{n}\right)$ which is the full employment growth rate. According to the construction of this model, the natural growth rate can result from an increase in population and technical progress. It therefore results from the employment of the economy's active population. It can therefore be seen as the rate at which the economy must grow to avoid unemployment. It is constant at $g_{n}=n$.

Nonetheless, the general implication from the above framework is that the growth rate of an economy has a positive correlation with the employment of the economy's active population and technical progress. Therefore, the more the employment of the economy's active population and technical progress, the greater the growth rate of national income per capital (GDPK). The weaknesses of the above model, which makes its general applicability limited, hinges on the fact 
that it is largely built on unrealistic assumptions. Nevertheless, it is a logical framework by which the incorporation of the economy's active population and technical progress (forms of natural resources) represents a suitable channel for natural resources to be used as agents of economic emergence.

The endogenous growth theories are also a theoretical foundation to this paper. These theories appeared in the 1980s with the work of Romer and Lucas (1988). These theories state that the growth rate of GDP per head is derived from the accumulation of internal factors. Endogenous growth theory holds that investment in human capital, innovation and knowledge are significant contributors to economic growth. The theory also focuses on positive externalities and the spillover effects of a knowledge-based economy which will lead to economic development. Their methodology consists of two main assumptions that is the production function has an increasing return to scale and that the marginal productivity of capital decreases to even zero level.

We also have the AK Model of Rebelo (1991)which states that the growth rate of an economy depends on the behaviour of agents and on the productivity of capital. Therefore, the AK Model describes the growth path where productivity increases at a constant rate as capital.

The general framework of the AK Model is that there is a production function and a saving equation as;

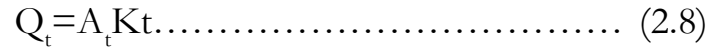

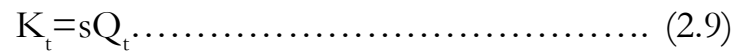

Where; Q is output, $\mathrm{K}$ is Capital, $\mathrm{s}$ is the rate of saving and $A$ is parameter of scale. We can therefore deduce from (2.8) and (2.9) that the growth rate of the economy given as $\frac{k}{k}=s A$. The AK Model which is the simplest endogenous growth theory gives a constant saving rate for endogenous growth. It models technological progress with a single parameter (A). This model assumes that the production function does not exhibit diminishing returns due to positive spillovers from the capital investments to the economy or improvements in technology leading to further improvements (learning-by-doing). In this work, technology is to be obtained through higher educational investments or acquisition.

Nonetheless, the general implication of the AK model is that the more their investments in human capital, innovation and knowledge, the more the growth rate of GDP per capita implying sustainable economic growth and development. Also, the greater the positive externalities and the spillover effects of knowledge in an economy (that is technological progress), the more the growth rate of GDP per capita signaling sustainable economic growth and development.

The applicability of the AK model is retarded by the fact that it destroys the base of the NeoClassical growth models (stability). Nevertheless, it is a logical framework in which its incorporation of endogenous savings and technological progress in terms of knowledge spillovers from investments in human capital (forms of natural resources) represents a suitable channel for natural resources to be used as agents of sustainable economic growth and development.

From the above empirical literature, it is deduced that very few studies have focused on natural resource and economic growth, development and emergence. Some of the studies focused on oil rent, some focused on timber exports, others on natural gas and coal rent. To the best of our knowledge, no single study has comprehensively assessed the effects of all the various strands of natural resources concerning the emergence of the 
economy of Cameroon. This creates the knowledge gap which this paper intends to fill.

\section{Methodology}

This study covers the period of 58 years starting from 1960 to 2017. This range is chosen due to availability of data and also given the fact that the natural resources enhancing growth variables have been under the indigenous Government all the while. Furthermore, this period is long enough to determine the strength of the existing potentials and expected potentials in assisting sustainable growth and development in Cameroon. Given the fact that natural resources are of two categories [those extracted with replacement and those extracted without replacement] this period is long enough to provide adequate insights into policy formulation in Cameroon based on natural resource enhancing factors. The study has also made use of statistical information, most of which are generated from the Cameroon financial bills African development indicators and World Bank data set.

The first specified model in this paper is a variant of series of models, among which is the $A K$ Model by Rablelot (1991), where there are two types of capital, physical and human capital modified to incorporate certain important variables that affect the economic emergence of Cameroon. These two types of capital are produced with the same technology. The total output of the economy is specified as a general functional relationship as follows;

$Q_{t}=F\left(K_{t}, H_{t}\right)=F\left(K_{t}, h_{t} L_{t}\right)$

Where, $\mathrm{F}$ is a neoclassical production function, $K_{t}$ is the aggregate capital (physical capital) in period $t, h_{t}$ is human capital per worker, and $H_{t}$ is $h_{t} L_{t}$, representing theeffective labour. Following the Cobb-Douglas specification, this general functional relationship is stated as follows;

$A_{t} L_{t}^{\alpha} K_{t}^{\beta} h_{t}^{\gamma}$
Where: $\mathrm{A}$ is the level of technology, $\mathrm{L}$ is labour input, $\mathrm{K}$ is capital input, $\quad \alpha, \beta$ and $\gamma$ are elasticities of production with respect to labour, physical capital and human capital respectively. Gross domestic product per capita (GDPPK) is the total output $(\mathrm{Q})$, school enrolment in the tertiary sector (SET) is the technological input (A), population growth rate (PGR) is the labour input $(\mathrm{L})$, \{availability of quality agricultural land (AAL), electricity supply (ES), total natural resource rents that is, mineral rent, natural gas rent and oil rent (TNRR), foreign direct investments (FDI), and gross domestic capital formation (GDCFGR) $\}$ is the aggregate capital input $(\mathrm{K})$. This study therefore augments the AK model by replacing the human capital by other forms of natural resources that affect the economic emergence of Cameroon. This can therefore be specified in the functional relationship as;

$G D P P K_{t}=f\left(S E T^{\emptyset}{ }^{\dagger}, A L_{t}^{\alpha}, E S_{t}^{\beta}, T N R R_{t}^{\gamma}, P G R_{t}^{\delta}, F D I_{t}^{\varepsilon}, G D C F G R_{t}^{\theta}, e^{\mu}\right) \ldots \ldots$

Taking the natural logs on both sides of equation (3.3) and taking care of the error term $(\mu)$ and the constant term, the relationship is econometrically stated in a model form as:

$\operatorname{InGDPPK_{t}}=\partial+\emptyset \operatorname{InSET} T_{t}+\alpha \operatorname{InAAL_{t}}+\beta \operatorname{InES} S_{t}+\gamma \operatorname{InTNRR_{t}}+$ $\delta I n P G R_{t}+\varepsilon \ln F D I_{t}+\theta G D C F G R_{t}+\mu_{t} \ldots \ldots \ldots$ (3.4)

Where $\partial, \emptyset, \alpha, \beta, \Upsilon, \delta, \varepsilon$ and $\theta$ are the coefficients to be estimated. The a priori expectations of this model are such that: $\partial \neq 0, \alpha>0, \beta>0, \Upsilon>0$ and $\delta$ $>0$ etc.

The specification approach adopted for this paper is the Structural Vector Auto-Regressive (SVAR) Modeling Approach. This is because the model has the capacity to eliminate the problems associated in estimating a model with multicolinearity. VAR is quite a pragmatic approach that is commonly used to examine the short- and long-term interactions between macroeconomic aggregates when it is established that all the variables in each equation are endogenous. In this study we have adopted the 
Structural Vector Auto-Regression (SVAR) framework, which has the ability to investigate into the roles of innovations on an economy and their possible determinations (SIM, 1982, 1986; Bernake and Blinder, 1992). Sims (1980) explains that VAR framework made it possible to direct both relative meaning the dynamic effect of the disturbances on macroeconomic variables. Its main criticism has been that it has a largely theoretical identification mechanism with little economic foundation (Cooley and Leroy, 1985). The SVAR methodology is observed to provide improvement on the identification mechanism by imposing restrictions based on economic theories. The methodology is focused on how innovations to one endogenous variable affect other endogenous variables and the direction of instant correlation between innovation variables can be assessed. It is also possible to determine any stocks within the period of study and whether it has temporary or permanent effect on the endogenous variables. The Structural Vector Auto-Regressive (SVAR) applied to this study composed of a system of eight equations representing eight endogenous variables structured as presented below;

Real Gross Domestic Product Per Capita Growth Equation

$$
\begin{aligned}
& R G D P P K_{t}=A_{0}+\sum_{i=1}^{58} A_{1} R G D P P K_{t-1}+ \\
& \sum_{i=1}^{58} A_{2} R G D P P K_{t-2}+\sum_{i=1}^{58} B_{1} A A L_{t-1}+ \\
& \sum_{i=1}^{58} B_{2} A A L_{t-2}+\ldots \ldots+\sum_{i=1}^{58} H_{1} G D C F G R_{t-1} \\
& +\sum_{i=1}^{58} H_{2} G D C F G R_{t-2}+\mu_{t 1} \ldots \ldots \ldots \ldots \ldots(3.5)
\end{aligned}
$$

And the Gross Domestic Capital Formation Growth Rate Equation

$$
\begin{aligned}
\text { InGDCFGR }_{t}= & H_{0}+\sum_{i=1}^{58} H_{1} G D C F G R_{t-1} \\
& +\sum_{i=1}^{58} H_{2} G D C F G R_{t-2}+\sum_{i=1}^{58} G_{1} F D I_{t-1}+\sum_{i=1}^{58} G_{2} F D I_{t-2}+\cdots \\
& +\sum_{i=1}^{58} A_{1} R G D P P K_{t-1}+\sum_{i=1}^{58} A_{2} \operatorname{RGDPPK}_{t-2}+\mu_{t 3} \ldots(3.6)
\end{aligned}
$$

The suitability of the above parameters is tested on the basis of three criteria namely; the economic or a priori criterion, the statistical or first order and the econometric or second order tests. The economic or a priori test is concerned with the magnitude (size) and direction (sign) of the estimated parameters. Through this criterion, examine the behavior of economic theories on the variables and the expected signs and sizes of the parameters in question with respect to a priori expectation. Consequently, the signs and magnitudes of the parameters are studied in agreement with the a priori expectations. Accordingly, the Phillip Perron, Dickey Fuller and Augmented Dickey Fuller unit root tests are adapted to test for stationarity of variables.

\section{Presentation and Discussion of Findings}

In favour of suitable policy recommendations, the data for this paper are subjected to numerated pretests and posttests of normality which are expected to justify the goodness of the suggested policies from the findings. Given the fact that we are concerned with predictions of the future with the use of previous years' data, the characteristics of these data must be examined. In this light, we briefly examine the normality of the data trends from 1960 to 2017 as presented in table 4.1 below. 
REVUE DE L'ACADEMIE DES SCIENCES DU CAMEROUN Vol. 15 No. 2 (Dec. 2019)

Table 4.1: Descriptive Statistics of Natural Resource Sustainability Variables.

$\begin{array}{lccccccccc} & \text { RGDPPK } & \text { AAL } & \text { ES } & \text { TNRR } & \text { PGR } & \text { SET } & \text { FDI } \\ \text { Mean } & 531079.9 & 18.77349 & 8.058012 & 8.833783 & 2.695953 & 4.472835 & 2.912624 & 13.94026 \\ \text { Median } & 521343.0 & 19.37760 & 2.932380 & 8.927710 & 2.693860 & 2.685950 & 1.732365 & 10.53054 \\ \text { Maximum } & 788218.0 & 25.62580 & 39.74400 & 17.38680 & 3.313590 & 19.57490 & 16.63123 & 78.03028 \\ \text { Minimum } & 374029.0 & 12.35820 & 1.059320 & 2.030700 & 2.019120 & 0.019120 & -0.853957 & -20.16040 \\ \text { Std. Dev. } & 105347.1 & 1.854554 & 10.59525 & 3.537594 & 0.277428 & 5.011476 & 3.766515 & 17.89783 \\ \text { Skewness } & 0.527403 & -0.079467 & 1.641844 & 0.270063 & -0.212096 & 1.601087 & 1.972568 & 1.170864 \\ \text { Kurtosis } & 2.495499 & 6.649192 & 4.153563 & 2.703108 & 2.917386 & 4.673796 & 6.284260 & 5.130027 \\ \text { Jarque-Bera } & 3.303915 & 32.24283 & 29.27383 & 0.918045 & 0.451345 & 31.55083 & 63.68028 & 24.21671 \\ \text { Probability } & 0.191674 & 0.000000 & 0.000000 & 0.631901 & 0.797979 & 0.000000 & 0.000000 & 0.000006 \\ \text { Sum } & 30802634 & 1088.862 & 467.3647 & 512.3594 & 156.3653 & 259.4244 & 168.9322 & 808.5349 \\ \text { Sum Sq. Dev. } & 6.33 \mathrm{E}+11 & 196.0441 & 6398.776 & 713.3305 & 4.387086 & 1431.549 & 808.6382 & 18258.95 \\ \text { Observations } & 58 & 58 & 58 & 58 & 58 & 58 & 5\end{array}$

\section{Source: Generated by Authors Using E-View Version 7}

The bounds of the variables are represented by the maximum for the upper band and the minimum for the lower band. With the exception of population growth rate (PGR) whose range is 1.294, all the other variables revealed wide range as such, wide variability. This calls for variance test (that is whether or not the data are normally distributed for the use of the Ordinary Least Squares technique for data estimation. Important is the evaluation of the link between the mean and median in an "open ended data". These links are presented in table 4.2 below.

Table 4.2: Nature of Performance of the Natural Resource Sustainability Variables.

$\begin{array}{lllllllll} & \text { RGDPPK } & \text { AAL } & \text { ES } & \text { TNRR } & \text { PGR } & \text { SET } & \text { FDI } & \text { GDCFGR } \\ \text { Mean } & 531.1 & 18.8 & 8.1 & 8.8 & 2.7 & 4.5 & 2.9 & 13.9 \\ \text { Median } & 521.3 & 19.4 & 2.9 & 8.9 & 2.7 & 2.7 & 1.7 & 10.5 \\ \text { Observed } & +9.8 & -0.6 & +5.2 & -0.1 & 0.0 & 1.8 & 1.2 & 3.4 \\ \text { Remarks } & \text { Good } & \text { Poor } & \text { Good } & \text { Poor } & \text { Normal } & \text { Good } & \text { Good } & \text { Good }\end{array}$

Source: Calculated by Authors Using Table 4.1

This table explains the fact that a sum of many independent and identically distributed (iid) random variables (the case of natural resources) will tend to be distributed according to one of a small set of attractor distribution but when the variance of the identically distributed (iid) variables is infinite, the attractor distribution is that of the normal distribution. In this case, it is true with population growth rate (PGR) in Cameroon. Though abnormality exist when the mean deviates from the median as in the case of natural resource variables, such deviations are considered good when the mean is greater than the median, and poor when the mean is less than the median in an infinite distribution. Thus, availability of quality agricultural land (AAL) and total rents (TNRR) from natural resources have not yielded much towards the emergence of Cameroon by 2035 .

Furthermore, examination of the kurtosis of each of the variables as presented in table 4.1 claims that variability of quality agricultural land (AAL), electricity supply (ES), tertiary educational enrolment (SET) and gross domestic capital formation (GDCF) growth rates are not normally distributed since they all have values greater than 
three (03). These are cases of Leptokurtic as such, their distribution follows the Laplace distribution which have tails that are asymptotically approaching zero more slowly than a Gaussian. Platykurtic such as real gross domestic product per capita (RGDPPK) and total natural resource rent (TNRR) are uniform distributions without positive value tails. Their skewness is positive meaning that proper management of these natural resource enhancing variables have the possibility of sustaining the predicted growth of Cameroon comes 2035 and beyond. Interestingly, the availability of quality land and population growth rate in Cameroon is negatively skewed. This explains the dependent of additional population on agriculture and continues extraction of the fertile land to marginal land as explained in the classical theory of the race between population growth (PG), agricultural land use and technological transfer that ends in stagnation. This link therefore suggests that for sustainable development, proper orientation should be given to the additional population outside the agricultural sector.

Going by the values of the Jarque-Bera for the natural resource sustainable variables, population growth and total natural resource rents have the capacity to predict absolutely the sustainability of the of economic emergence of Cameroon by 2035 and beyond. The claim here is that since the data set is from 1960 to 2017, that is 58 years, population growth and total natural resource rents have the capacity to explain sustainable growth in Cameroon up to 2075. That is 40 years beyond its emergence.

However, given the fact that descriptive statistics have no critical values, further tests are needed to properly justify the degrees of responsiveness of sustainable growth post emergence. Among such tests is the pair wise correlation matrix table which is also the test of multicolinearity (goodness of fit of the relationship between the variables as they explain the behaviour of the dependent variable. These are presented in table 4.3 below.

Table 4.3 Pair Wise Correlation Table and Levels of Significance of the Variables

\begin{tabular}{lcccccccc} 
& \multicolumn{3}{c}{ RGDPPK } & AAL & ES & \multicolumn{2}{c}{ TNRR } & \multicolumn{2}{c}{ PGR } & SET & FDI \\
RGDPPK & 1.000000 & 0.639183 & 0.319562 & 0.125601 & 0.793149 & 0.388541 & -0.417952 & -0.002288 \\
AAL & 0.639183 & 1.000000 & 0.598363 & 0.063529 & 0.661536 & 0.757927 & -0.590702 & -0.029386 \\
ES & 0.319562 & 0.598363 & 1.000000 & -0.028261 & 0.155308 & 0.887344 & -0.131767 & 0.029405 \\
TNRR & 0.125601 & 0.063529 & -0.028261 & 1.000000 & -0.010253 & -0.041634 & 0.105942 & -0.298785 \\
PGR & 0.793149 & 0.661536 & 0.155308 & -0.010253 & 1.000000 & 0.194526 & -0.591035 & 0.152621 \\
SET & 0.388541 & 0.757927 & 0.887344 & -0.041634 & 0.194526 & 1.000000 & -0.283386 & -0.117248 \\
FDI & -0.417952 & -0.590702 & -0.131767 & 0.105942 & -0.591035 & -0.283386 & 1.000000 & -0.107310 \\
GDCFGR & -0.002288 & -0.029386 & 0.029405 & -0.298785 & 0.152621 & -0.117248 & -0.107310 & 1.000000
\end{tabular}

\section{Source: Generated by Authors Using E-View Version 7}

Based on the Z-test of significance, since $\mathrm{n}>30$, $\mathrm{Z}=\sqrt[r]{n-1}$, all the values are significant at less than $10 \%$ level of significance. We observe that some degrees of relationship exist between the dependent and the independent variables of this study but for the purpose of the test, the $\operatorname{Cov}(\mathrm{ES}$, SET) $>0$, that is 0.887 . This value is close to linearity meaning that their inclusion in a time series model analysis captures the influence of each other. For better outcome, split half analysis is required. By so doing, the problem of multicollinearity is eliminated. Going by the fact that deviations exist between the means of the variables and their medians, and the fact that the range is justified by the maximum and minimum bound of the variables are wide, the graphs of the variables are needed to determine whether they have trends or not, and if they do, what are 
the nature of the trends (deterministic or stochastic), and whether they are drifts or without drifts and whether they are truncated or not. The graphs are presented in appendix 1. The insights drawn from the graphs are that; they have drifts, they are not truncated and they have no particular trend. However, high degrees of stochastic trends are observed with total natural resource rents (TNR), foreign direct investments and gross domestic capital formation growth rate which are catalyst to natural resources sustainability.
The absence of truncations in any of the variables eliminates the Kwiatkowski Philip's Schmidt-Shin test, Eliott-Rothenbeng-Stock Point-Optimal test and $\mathrm{Ng}$ Perron tests of stationarity (unit root tests) in favour of the Dickey Fuller GLS (ERS), Augmented Dickey Fuller and the Phillip's Perron tests also called the traditional unit root tests. They are presented as shown in table 4.4 .

Table 4.4 Unit Root Tests of the Inclusive Variables

\begin{tabular}{|c|c|c|c|c|c|c|c|c|}
\hline Variables & $\overline{D F}$ & Remark & $\mathrm{ADF}$ & Level & Remark & PP & Level & Remark \\
\hline RGDPPK & -2.404 & Not St & -10.043 & $2^{\text {nd }}$ diff & St & -5.106 & $1^{\text {st }}$ diff & St \\
\hline LogES & -0.153 & Not St & -5.771 & $1^{\text {st }}$ diff & St & -5.766 & $1^{\text {st }}$ diff & St \\
\hline LogFDI & -3.834 & Not St & -11.317 & $1^{\text {st }}$ diff & St & -5.766 & $1^{\text {st }}$ diff & St \\
\hline GDCFGR & -8.093 & $\mathrm{St}$ & $\checkmark$ & Level & $\mathrm{St}$ & -8.119 & Level & $\mathrm{St}$ \\
\hline PGR & -1.616 & Not St & -0.145 & $2^{\text {nd }}$ diff & Not St & -0.149 & $2^{\text {nd }}$ diff & Not St \\
\hline LogSET & 0.044 & Not St & -30.328 & $1^{\text {st }}$ diff & St & -31.545 & $1^{\text {st }}$ diff & St \\
\hline TNRR & -4.104 & St & $\checkmark$ & Level & $\mathrm{St}$ & -4.181 & Level & St \\
\hline LogAAL & 1.887 & Not St & -1.681 & $2^{\text {nd }}$ diff & Not St & -9.595 & $1^{\text {st }}$ diff & $\overline{\mathrm{St}}$ \\
\hline \multicolumn{4}{|c|}{ Critical Values } & \multirow{5}{*}{\multicolumn{5}{|c|}{$\begin{array}{l}\text { Note: } \mathrm{DF}=\text { Dickey Fuller Test } \\
\mathrm{ADF}=\text { Augmented Dickey Fuller Test } \\
\mathrm{PP}=\text { Phillips Perron Test } \\
\mathrm{St}=\text { Stationarity or Integration in a Certain Order }\end{array}$}} \\
\hline & $1 \%$ & $5 \%$ & $10 \%$ & & & & & \\
\hline DF & -3.557 & -2.917 & -2.596 & & & & & \\
\hline $\mathrm{ADF}$ & -3.553 & -2.915 & -2.595 & & & & & \\
\hline PP & -3.553 & -2.915 & -2.595 & & & & & \\
\hline
\end{tabular}

Source: Generated by Authors Using E-View Version 7

Table 4.4 is designed to ascertain the presence or absence of unit root problem, this is because its presence in an Auto-Regressive (AR) Process generates a number of effects on the distribution of the Lease Squares estimators. One of such problems is spurious regression when variables of different status are regressed in the same model. In table 4.4, the variables are integrated at levels, first difference and second difference except with population growth rate which is not integrated at even the second difference of logarithms for the Phillips-Perron unit-root test. Given all conditions before now, our model eliminates the variables with strong linearity and those which are not integrated at any order of integration if the OLS were used. Our reduced form model becomes;

$$
\begin{aligned}
D D G D P P K_{t}= & \propto_{0}+\propto_{1} D \ln E S_{t}+\propto_{2} D \ln F D I_{t}+\propto_{3} D \ln S E T_{t}+\propto_{4} T N R R_{t}+\propto_{5} D D \ln A A L_{t} \\
& +\propto_{6} G D C F G R_{t}+\mu_{t} \ldots \ldots \ldots \ldots \ldots \ldots \ldots \ldots \ldots \ldots \ldots
\end{aligned}
$$

This model is estimated using the SVAR methodology. 
Table 4.5 Structural Vector Auto-Regression (SVAR) Results

\begin{tabular}{|c|c|c|c|c|c|c|c|c|}
\hline & RGDPPK & AAL & ES & TNRR & PGR & SET & FDI & GDCFGR \\
\hline $\begin{array}{l}\text { DLRGDPPK(- } \\
\text { 1) }\end{array}$ & $\begin{array}{l}0.0775 \\
(2.422)^{*}\end{array}$ & $\begin{array}{l}-0.2643 \\
(-3.164)^{*}\end{array}$ & $\begin{array}{l}0.042 \\
(1.83)^{* *}\end{array}$ & $\begin{array}{l}0.1483 \\
(1.772)^{* * *}\end{array}$ & $\begin{array}{l}0.7231 \\
(3.229)^{*}\end{array}$ & $\begin{array}{l}0.4165 \\
(2.462)^{*}\end{array}$ & $\begin{array}{l}-0.328 \\
(-0.2501)\end{array}$ & $\begin{array}{l}-0.3518 \\
(-1.0662)\end{array}$ \\
\hline $\begin{array}{l}\text { DLRGDPPK(- } \\
\text { 2) }\end{array}$ & $\begin{array}{l}0.05789 \\
(1.94211)^{* *}\end{array}$ & $\begin{array}{l}0.1514 \\
(1.3736)\end{array}$ & $\begin{array}{l}0.6645 \\
(2.16)^{*}\end{array}$ & $\begin{array}{l}0.66428 \\
(3.142)^{*}\end{array}$ & $\begin{array}{l}0.2261 \\
(1.4116)\end{array}$ & $\begin{array}{l}0.6219 \\
(4.403)^{*}\end{array}$ & $\begin{array}{l}0.469 \\
(3.121)^{*}\end{array}$ & $\begin{array}{l}0.1653 \\
(4.946)^{*}\end{array}$ \\
\hline DLAAL(-1) & $\begin{array}{l}0.4327 \\
(1.4031)\end{array}$ & & & $\begin{array}{l}0.12089 \\
(1.728)^{* * *}\end{array}$ & $\begin{array}{l}0.63171 \\
(4.901)^{*}\end{array}$ & & $\begin{array}{l}0.618 \\
(3.541)^{*}\end{array}$ & $\begin{array}{l}-0.4362 \\
(-2.613)^{*}\end{array}$ \\
\hline DLAAL(-2) & $\begin{array}{l}0.5414 \\
(1.2332)\end{array}$ & & & $\begin{array}{l}0.53016 \\
(1.846)^{* *}\end{array}$ & $\begin{array}{l}0.4412 \\
(1.772)^{* *}\end{array}$ & & $\begin{array}{l}0.53016 \\
(1.846)^{* *}\end{array}$ & $\begin{array}{l}0.6379 \\
(2.096)^{*}\end{array}$ \\
\hline DLES(-1) & $\begin{array}{l}0.5233 \\
(3.1161)^{*}\end{array}$ & & & $\begin{array}{l}0.74103 \\
(3.1614)^{*}\end{array}$ & $\begin{array}{l}0.6121 \\
(1.781)^{* *}\end{array}$ & $\begin{array}{l}0.4192 \\
(2.613)^{*}\end{array}$ & $\begin{array}{l}0.4216 \\
(1.411)\end{array}$ & $\begin{array}{l}0.3412 \\
(0.6912)\end{array}$ \\
\hline DLES(-2) & $\begin{array}{l}0.5421 \\
(2.614)^{*}\end{array}$ & & & $\begin{array}{l}0.6462 \\
(2.3204)^{*}\end{array}$ & & $\begin{array}{l}0.31161 \\
(4.211)^{*}\end{array}$ & $\begin{array}{l}0.294 \\
(1.82)^{* *}\end{array}$ & $\begin{array}{l}0.4052 \\
(1.862)^{* *}\end{array}$ \\
\hline TNRR(-1) & $\begin{array}{l}0.3416 \\
(3.381)^{*}\end{array}$ & & & $\begin{array}{l}0.398 \\
(1.968)^{* *}\end{array}$ & $\begin{array}{l}0.6212 \\
(3.41)^{*}\end{array}$ & $\begin{array}{l}0.1361 \\
(2.714)^{*}\end{array}$ & & $\begin{array}{l}0.6413 \\
(1.9864) * *\end{array}$ \\
\hline TNRR(-2) & $\begin{array}{l}0.4316 \\
(1.976)^{* *}\end{array}$ & & & $\begin{array}{l}-0.1864 \\
(-1.655)\end{array}$ & $\begin{array}{l}0.46381 \\
(1.962)^{* *}\end{array}$ & $\begin{array}{l}0.3741 \\
(2.562)^{*}\end{array}$ & & $\begin{array}{l}0.29612 \\
(2.3413)^{*}\end{array}$ \\
\hline PGR(-1) & $\begin{array}{l}0.8461 \\
(5.233)^{*}\end{array}$ & $\begin{array}{l}-0.6433 \\
(-4.1962)^{*}\end{array}$ & & $\begin{array}{l}0.2831 \\
(1.8211)^{* *}\end{array}$ & $\begin{array}{l}0.0421 \\
(0.061)\end{array}$ & $\begin{array}{l}0.6421 \\
(5.1182)^{*}\end{array}$ & & $\begin{array}{l}0.7341 \\
(7.451)^{*}\end{array}$ \\
\hline PGR(-2) & $\begin{array}{l}0.4922 \\
(3.211)^{*}\end{array}$ & $\begin{array}{l}-0.9421 \\
(-2.312)^{*}\end{array}$ & & $\begin{array}{l}0.2664 \\
(1.2191)\end{array}$ & $\begin{array}{l}0.056 \\
(0.314)\end{array}$ & $\begin{array}{l}0.6833 \\
(4.221)^{*}\end{array}$ & & $\begin{array}{l}0.5834 \\
(6.1215)^{*}\end{array}$ \\
\hline DLSET(-1) & $\begin{array}{l}0.7761 \\
(6.3411)^{*}\end{array}$ & $\begin{array}{l}0.4611 \\
(2.714)^{*}\end{array}$ & $\begin{array}{l}0.214 \\
(5.112)^{*}\end{array}$ & $\begin{array}{l}0.3814 \\
(6.113)^{*}\end{array}$ & $\begin{array}{l}-0.6628 \\
(3.161)^{*}\end{array}$ & & $\begin{array}{l}-4.161 \\
(-2.412)^{*}\end{array}$ & $\begin{array}{l}0.7764 \\
(4.113)^{*}\end{array}$ \\
\hline DLSET(-2) & $\begin{array}{l}0.64415 \\
(4.691)^{*}\end{array}$ & $\begin{array}{l}0.3821 \\
(1.914)^{* *}\end{array}$ & $\begin{array}{l}0.6115 \\
(1.713)^{* *}\end{array}$ & $\begin{array}{l}0.1152 \\
(1.431)\end{array}$ & $\begin{array}{l}-0.741 \\
(2.938)^{*}\end{array}$ & & $\begin{array}{l}0.338 \\
(1.442)\end{array}$ & $\begin{array}{l}0.6912 \\
(3.141)\end{array}$ \\
\hline DLFDI(-1) & $\begin{array}{l}0.2233 \\
(3.144)\end{array}$ & $\begin{array}{l}0.4116 \\
(2.236)\end{array}$ & $\begin{array}{l}0.4112 \\
(1.87)^{* *}\end{array}$ & $\begin{array}{l}0.0156 \\
(2.221)^{*}\end{array}$ & & $\begin{array}{l}0.2619 \\
(4.613)^{*}\end{array}$ & $\begin{array}{l}0.0142 \\
(3.161)^{*}\end{array}$ & $\begin{array}{l}0.1225 \\
(4.339)^{*}\end{array}$ \\
\hline DLFDI(-2) & $\begin{array}{l}0.0142 \\
(1.796)^{* *}\end{array}$ & $\begin{array}{l}0.6912 \\
(11.318)^{*}\end{array}$ & $\begin{array}{l}0.014 \\
(1.941)^{* *}\end{array}$ & $\begin{array}{l}0.2216 \\
(2.2941)^{*}\end{array}$ & & $\begin{array}{l}0.7332 \\
(6.141)^{*}\end{array}$ & & $\begin{array}{l}0.6419 \\
(4.336)\end{array}$ \\
\hline GDCFGR(-1) & $\begin{array}{l}0.2611 \\
(1.446)\end{array}$ & & & $\begin{array}{l}0.3961 \\
(1.962)^{* *}\end{array}$ & $\begin{array}{l}0.3194 \\
(2.685)^{*}\end{array}$ & $\begin{array}{l}0.0041 \\
(1.036)\end{array}$ & & $\begin{array}{l}0.8558 \\
(4.062)^{* *}\end{array}$ \\
\hline GDCFGR(-2) & $\begin{array}{l}0.1231 \\
(2.448)^{* *}\end{array}$ & & & $\begin{array}{l}0.9341 \\
(4.449)^{*}\end{array}$ & $\begin{array}{l}0.0231 \\
(1.6621)\end{array}$ & $\begin{array}{l}0.164 \\
(1.793)^{* *}\end{array}$ & & $\begin{array}{l}0.6516 \\
(12.639)^{*}\end{array}$ \\
\hline $\bar{R}^{2}$ & 0.864 & 0.569 & 0.743 & 0.564 & 0.842 & 0.751 & 0.622 & 0.673 \\
\hline F-Statistics & 16.371 & 5.192 & 11.34 & 5.83 & 17.83 & 10.58 & 6.121 & 10.58 \\
\hline Loglikelihood & 0.43 & 0.32 & 0.51 & 0.85 & 0.75 & 0.61 & 0.86 & 0.44 \\
\hline
\end{tabular}

Source: Generated by Authors Using E-View Version 7

From the table 4.5, the study aims at examining how sustainable growth and development can be achieved in Cameroon through natural resources enhancing indicators. The quantitative result reveals that gross domestic product per capital used as proxy for sustainable growth is influenced positively by one year and two year lagged values of availability of quality agricultural lands, and lagged values, current and previous year energy supply, current and previous years foreign direct investment, tertiary education enrolment past and present, total natural resources rent, gross domestic capital formation growth, current and past values, and population growth, present and past values. While all the coefficients are significant at the less than 10 percent level of significance, availability of quantity and quality agricultural land past and present gross domestic capital formation growth lagged one year are not significant even at the 10 percent level of significance. The insignificance of availability of quality agricultural land is a cause for concern. This is also the case with gross domestic capital formation growth. From the above findings it is clear that the specified variables are instrumental in enhancing sustainable growth in Cameroon. The inclusive variables account for 86.4 percent of variation in sustainable growth in Cameroon with less than 13.6 percent accounted for by the un-explained variation. Given the fact that available quality agricultural land is fixed, adjustments can only be possible through land reclamation or improvement on the quality of the existing one. Our quantitative result reveals that gross domestic per capital lagged one negatively influences the ability of quality agricultural lands as it is with the case 
of current and previous population growth rate. These variables are significant at one percent level of significance meaning that any policy aims at justifying the availability of quality land use must consider population growth rate and real gross domestic product per capita.

Though the above-mentioned factors exert negative influence, real domestic per capita lagged two years, foreign direct investment current and previous positively influence the variation of quality agricultural land. This variable accounts for more than 56.9 percent variations with the availability of quality agricultural land with less than 43.1 percent accounted for by the unexplained variation. Therefore, by implication the inclusive significant variable must be used for policy directed towards the improvement of quality and quantity of lands in Cameroon.

Energy supply is considered for enhancing growth and development in Cameroon. While energy supply in most advanced countries has evolved from cool, hydroelectricity to solar energy, Cameroon households are dominated by electrical energy mostly from hydropower systems. This study hereby reveals that gross domestic product per capita, current and past values, foreign direct investment, current and past values, and student's enrolment at the tertiary educational level positively and significantly enhance energy supply. Therefore, any attempt to advocate sustainable energy supply, the advocates must enhance real gross domestic product per capita growth, foreign direct investments and tertiary education enrolment rate. The findings account for more than 74.3 percent variation in energy supply with less than 25.7 percent variation accounted for by the unexplained variations.

The outstanding debate between the classical economists and the endogenous growth school on whether or not foreign direct investment matters, continues in this study. While real gross domestic product per capita lagged two years, availability of agricultural land, current and previous energy supply, lagged for one year, FDI itself positively and significantly influence FDI inflows while one year lagged real gross domestic product per capita, one year lagged tertiary educational enrolment are hereby seen as significant FDI retarding indicators. Jointly, both set of variables account for 62.2 percent of variations in FDI in Cameroon while 37.8 percent are directed to the unexplained variations. In all, this work seems to stand in favour of FDI inflows as suggested by the classical economists that because of low level of income and savings, the vicious cycle of poverty can only be dismounted by foreign capital inflows. While the endogenous growth advocates see this as the reason for continuous dependency of the less developed countries for capital from the advanced economies, they are of the view that growth and development in countries like Cameroon can only be achieved and sustained when such capital has emerged from within. This justifies the inclusion of gross domestic capital formulation growth in the study.

The gross domestic capita find favour in this study with the two year lag of available agricultural land,current and previous year energy supply, current and previous years foreign direct investment, present and previous years tertiary educational investments, total natural resources rent of one and two years lagged, previous year gross capita formation growth rate itself and previous year population growth rate. These findings are not only positive but they are significant at less than 10 percent level of significance. Contrary to the above are the coefficients of one year lagged of real gross domestic product per capita, one year lagged of availability of quality agricultural land, that significantly retard capital formation. Both sets of factors jointly account for $69.12 \%$ in the variation of gross domestic capital formation growth rate while 38.88 percent is accounted for by unexplained variations. 
In line with the endogenous growth hypothesis, internally generated resources are capable of sustaining the economy more than imported resources and technology. On this note the total natural resource rent is included in the model. All the variables with their lagged positively and significantly influence total natural resource rent except the total nature resource rent lagged two years which is not statistically significant. Therefore, the total natural resources have the capacity of increasing with increase in gross national product per capita, availability of quality agricultural land, energy supply, foreign direct investment, tertiary educational enrolment, gross domestic capital formation among others. Hence, variation in the total natural resources rent is about 56.4 percent accounted for by variation in the variables specified in the model with less than 44.6 percent in favour of the unexplained variation.

Studies have confirmed the preposition that educational enrolments positively related to natural resources conservation. This trend increases rapidly with increase in the level of enrolment especially in higher technical education that gives room for recycling than continuous extraction. The link between tertiary education and real domestic product per capital income, one and two years lagged energy supply, one and two years lagged foreign direct investment one and two years lagged of natural resource rent, one and two years lagged of gross domestic formation one and two years lagged of population growth are not only positive but significant at less than ten percent level of significance. This accounts for about 75.1 percent variation in tertiary education enrolment with about 24.9 percent accounted for by the unexplained variation. Based on the statistical significance of our findings, we strongly suggest that for any policy aimed at enhancing sustainable development in Cameroon via tertiary educational trainings and utilization, must consider the tertiary educational enhancing indicators.

Population has been seen by different study as a useful tool for sustainable growth and development. Today the world population and their location justify the world's partial development. That is the case with U SA, China, India, and Nigeria just to name a few. Talking about emergence and sustainable development, it is a fact that population is seen as a catalyst and in this study, only tertiary education is seen as the retarding factor to the population growth in Cameroon. Population enhancing growth variable accounts for about 84.2 percent of the variation of population growth in Cameroon while 15.8 percent is accounted for by the error term. While all the variables have the coefficient of determination of more than 50 percent, the likelihood of their occurrence is on the average above 50 percent. Since the SVAR results are based on the current and conditional one year and two years lagged responses, there is need to establish whether or not a long run equilibrium relationship exist between the variables. And if they do, simulation is conducted for variation of the real domestic product per capita beyond 2035. These are presented in the following section.

\section{Co-integration Tests}

The findings based on Dickey Fuller, the Augmented Dickey Fullerand the Phillips-Perron reveal that most of the time series data were not stationary but attained stationarity after their first or second difference. However, the focus of this work is to establish the long-run relationship between real gross per capita growth and its determinants, we advance here with the examination of this relationship using the EngleGranger (1987) two steps procedures which is not presented due to space. The regression residuals which are found to have zero mean and constant variance still exhibit some degrees of stochastic trends. Based on the fact that the coefficient of 
the error correction mechanism of -0.834did not satisfy our hypothesis of no co-integration, it therefore indicates that 83.2 percent of the previous disequilibrium was eliminated in the current period with immediate adjustment as captured by the difference terms.

However, in view of the limitation associated with the Engle-Granger Co-integration analysis, our studies are further validated using the Johansen (1991, 1995) and his approach which provides a number of co-integration equations as well as the estimate of all the co-integrating vectors in a multivariate analysis. The Johansen co-integration test findings are presented in table 4.5.

\section{Table 4.5 Co-integration Results}

Sample (adjusted): 1963/ 2017

Included observations: 55 after adjustments

Trend assumption: Linear deterministic trend

Series: GDPPKG AAL ES TNRR PGR SET FDI

GDCFGR

Lags interval (in first differences): 1 to 1

Unrestricted Cointegration Rank Test (Trace)

\begin{tabular}{lllll}
\hline \hline $\begin{array}{l}\text { Hypothesized } \\
\text { No. of CE }(\mathrm{s})\end{array}$ & Eigenvalue & $\begin{array}{l}\text { Trace } \\
\text { Statistic }\end{array}$ & $\begin{array}{l}0.05 \\
\text { Critical Value }\end{array}$ & Prob.** \\
\hline \hline None * & 0.708325 & 218.0532 & 159.5297 & 0.0000 \\
At most 1 $*$ & 0.496203 & 150.2868 & 125.6154 & 0.0007 \\
At most 2* & 0.439714 & 112.5799 & 95.75366 & 0.0021 \\
At most 3* & 0.407045 & 80.71791 & 69.81889 & 0.0052 \\
At most 4 & 0.337593 & 51.97293 & 47.85613 & 0.0195 \\
At most 5 & 0.260971 & 29.31979 & 29.79707 & 0.0567 \\
At most 6 & 0.205998 & 12.68679 & 15.49471 & 0.1268 \\
At most 7 & $3.11 \mathrm{E}-08$ & $1.71 \mathrm{E}-06$ & 3.841466 & 0.9996 \\
\hline \hline
\end{tabular}

Trace test indicates 5 cointegratingeqn(s) at the 0.05 level

* denotes rejection of the hypothesis at the 0.05 level

**MacKinnon-Haug-Michelis (1999) p-values

Unrestricted Cointegration Rank Test (Maximum Eigenvalue)

\begin{tabular}{lllll}
\hline \hline $\begin{array}{l}\text { Hypothesized } \\
\text { No. of CE(s) }\end{array}$ & Eigenvalue & $\begin{array}{l}\text { Max-Eigen } \\
\text { Statistic }\end{array}$ & $\begin{array}{l}0.05 \\
\text { Critical Value }\end{array}$ & Prob.** \\
\hline \hline None * & 0.708325 & 67.76633 & 52.36261 & 0.0007 \\
At most 1 & 0.496203 & 37.70695 & 46.23142 & 0.3027 \\
At most 2 & 0.439714 & 31.86196 & 40.07757 & 0.3106 \\
At most 3 & 0.407045 & 28.74499 & 33.87687 & 0.1812 \\
At most 4 & 0.337593 & 22.65314 & 27.58434 & 0.1888 \\
At most 5 & 0.260971 & 16.63300 & 21.13162 & 0.1900 \\
At most 6 & 0.205998 & 12.68679 & 14.26460 & 0.0874 \\
At most 7 & $3.11 \mathrm{E}-08$ & $1.71 \mathrm{E}-06$ & 3.841466 & 0.9996 \\
\hline \hline
\end{tabular}

Max-eigenvalue test indicates 1 cointegratingegn(s) at the 0.05 level

* denotes rejection of the hypothesis at the 0.05 level

**MacKinnon-Haug-Michelis (1999) p-values

Source; Generated by Authors from Eview Version 7 
The trace statistics and the max-Eigen tests were conducted to determine the number of cointegrating relations associated with each of the equations. While the trace statistics are presented in the first part of table 4.5, the max Eigen findings are presented in the second part of the same table. Since the null hypothesis of no cointegrated equation is rejected when the trace statistics is greater than the critical findings at 5 percent level of significance, it is therefore observed from the findings that at most four Cointegrated equations are established in this sturdy. Following the unrestricted normalized cointegrated coefficients, we observed that the variables in the different equations are relatively important. Based on the likelihood ratio (trace) test, the best and most significant vector is selected as presented below. The consistency in the test findings confirms the existence of a longrun relationship between the exogenous and the dependent variables in the model. On the trend of the error correction mechanism (ECM) variable the specification is presented thus:

$$
\begin{aligned}
& D L G D P P K G={ }_{(0.183)}^{0.658} D A A L+{ }_{(0.274)}^{0.461} D E S+ \\
& \underset{(0.397)}{0.886} D T N R+\underset{(0.0614)}{0.633} D L P G R+{ }_{(0.314)}^{0.854} D L S E T+ \\
& { }_{(0.194)}^{0.804} D F D I+{ }_{(0.1066)}^{0.616} D L G D C F G R+12.88 . .
\end{aligned}
$$

The standard errors presented in parenthesis are used for the calculation of the t-values of the different coefficients and the conclusion arrived at is that they are all significant at less than 10 percent levels of significance. The long-run equilibrium equation reveals that on the average all the variables specified in our model positively enhance the real gross domestic product per capita growth with total natural resources rents seen as an impact variable with a coefficient of 0.886, follows by tertiary education enrolment with the coefficient of 0.854 and foreign direct investments with the coefficient of 0.804 . Availability of quality agricultural land, population growth rate and gross domestic capital growth rate formed the second group of impact variables with their coefficient as $0.658,0.633$ and 0.616 respectively.

Considering the fact that the short term equilibrium adjust faster than the coefficient of the Co- integration error correction mechanism and the fact that a long run Co-integration equilibrium equation satisfied our predictions, it is possible to use the existing findings to forecast the behaviour of the specified variables in 2075 , that is 58 years out of the equal period of the utilized data set. Before stimulating the model for policy reforms, it is necessary to determine how best the equilibrium model explains the situation in the economy of Cameroon over the period of the study. This is done first by examining the trends of the behaviour of the variables specified in the real domestic product per capita growth equation. The tracking performance of the variables shows that from 1960 to 2017, a lot of turning errors are identified. This was highly minimized in the population growth rate trend. The volatility of the rest of the variables are a cause for concern when the simulations are to be conducted. This calls for further econometrics test for the forecasting power of our model as presented in the Table 4.6. Table 4.6 evaluates the Forecasting Power of the Model. (Real gross domestic product per capita growth).

Table 4.6: Tests of Forecasting

\begin{tabular}{|l|l|}
\hline Correlation coefficient & 0.86784 \\
\hline Root-mean square error & 0.3774 \\
\hline Mean error & 0.00211 \\
\hline Thieles equality coefficient & 0.24009 \\
\hline
\end{tabular}

Source: Calculated by Authors using E-view 7 
Table 4.6 reveals that a strong positive relationship of 0.86784 exist between the actual generated RGDPPK and the predicted RGDPPK in Cameroon on the bases of which the course of events can be forecasted. Infarct the model predicts a strong positive change in the RGDPPK due to the unit changed in the predicted variables. The evaluation in the forecasting power based on the values of root mean squared (0.03774), mean error (0.00211) and the Thieles inequality coefficient (0.24009) explains that the model forecast very well the situation of the RGDPPK in Cameroon as such is eligible for long run policy recommendation. This is conducted by predicting the variation of RGDPPK due to 4.91417 (0.702) on the average of the coefficient of the inclusive variables in the long run equilibrium model presented above. While the 70.2 percent dynamic policy simulation results are not presented in this work due to space, the summary is presented thus;

\begin{tabular}{llll}
\hline Variable & \multicolumn{1}{c}{$\begin{array}{c}\text { Actual } \\
\text { Value \% }\end{array}$} & $\begin{array}{l}\mathbf{7 0 . 2 \%} \\
\text { Increase }\end{array}$ & $\begin{array}{l}\mathbf{7 0 . 2} \% \\
\text { Decrease }\end{array}$ \\
\hline $\begin{array}{l}\text { Available } \\
\text { Agricultural land }\end{array}$ & 65.8 & 48.5 & -48.5 \\
$\begin{array}{l}\text { Energy Supply } \\
\begin{array}{l}\text { Total natural } \\
\text { resource rent }\end{array}\end{array}$ & 46.1 & 338.8 & -338.8 \\
$\begin{array}{l}\text { Population } \\
\text { growth rate }\end{array}$ & 63.3 & 651.7 & -651.7 \\
$\begin{array}{l}\text { Tertiary } \\
\text { education } \\
\text { enrolment }\end{array}$ & 85.4 & 465.3 & -465.3 \\
$\begin{array}{l}\text { Foreign direct } \\
\text { investment }\end{array}$ & 80.4 & 627.7 & -627.7 \\
$\begin{array}{l}\text { Gross domestic } \\
\text { formation G. }\end{array}$ & 61.6 & 590.9 & -590.9 \\
Average & 70.5 & 515.82 & -515.82 \\
\hline
\end{tabular}

Source: Calculated by Authors using E-view 7

The table 4.7 is a summary of the simulation results by the average values of the long run equilibrium. It reveals the actual values of the coefficient of the predicted values of what they should be by 2075 that is 58 years from today. Based on the findings, the following policy recommendations are made:

\section{Summary and Concluding Remarks}

Since real gross domestic product per capita growth used as proxy for measuring economic emergence has been unfolded, it is certain that the strategies enhancing growth-led sustainable development in Cameroon must operate on many fronts. Based on the high coefficient of our specified models, real gross domestic product per capita growth responses faster to total natural resources rents than it did with the other explanatory variables specified in the RGDPPK equation. Therefore, the part of wisdom for sustainable growth in Cameroon is to properly manage its rent from natural resources. Natural resources can be increased through the promotion of indigenous technology by the Government, land reclamation and through the encouragement of higher education enrolment. It is clearly observed that Cameroon is highly endowed with numerous natural resource deposits, some identified while others are still to be identified. Less than 50 percent of Cameroon is actually involved in the management of these resources to earn their total rent. Thus, management of these resources by Cameroonians will retain more than 80 percent of direct capital flight from Cameroon and hence better sustainable development.

Emphasis needs to be directed towards the development or training of efficient manpower by credible higher education institutions with curriculums designed to meet the societal needs. Here, institutions for the training of scientists, technicians and engineers are highly recommended. The current educational orientation in Cameroon where more than 60 per of those enrolled in higher education are in the fields of Art, Humanity and Social Sciences needs to be discouraged. The creation of professional schools without equipment is also considered unproductive. Therefore, more incentives such as subsidies, scholarships among others should be programmed for students opting for science, and 
technology, engineering and mathematics (STEM). This will go a long way to train the needed manpower for the economy of Cameroon and beyond.

Foreign direct investment should be directed to the real sector of the economy. In this case, more than 20 percent of the profit generated by foreign firms in Cameroon should be directed towards research, higher education infrastructure and corporate social responsibilities; the lack of which accounts for poverty, under development and misplacement of the development track in Cameroon. Due to the absence of research on development, Cameroon at 2018 is not different from that of the 1960s.

Provision of quality education and the promotion of educational training towards national development will ameliorate the quality of land available for agricultural end product as raw material for the industrial sector. Research has shown that more than 72 percent of the total agricultural output of Cameroon is not effectively and efficiently utilized in Cameroon. Continuous extraction and exploitation without replacement and lack of storage facilities render this sector more of energy lost than energy gain.

Research directly towards agricultural value added on food security should occupy significant portion of government budget as well as those of foreign investors. While emphasis is directed toward reorientating population growth, government must take its responsibility towards quality education at all levels, infrastructural development, health care services among others. For sustainable development to forge ahead, hard work must be part and parcel of Cameroonians. As domestic capital formation contribution is one of the least to sustainable development in Cameroon, it is observed that most Cameroonians consume more than what they produce and can boast of as such of little or no savings. Therefore, it is possible that the level of gross capital formulation can be improved if the philosophy of Cameroonians towards work improves.
Cameroon has put in place a lot of measures to achieve emergence by 2035. These are seen in the areas of economic growth and economic stability via poverty reduction and stability, expansionary monetary policy, agricultural-led development among others. However, this work aims at investigating whether or not the natural resources and natural resources enhancing indicators are capable of sustaining the economy post emergence. While the outcome is in agreement with the alternative hypothesis of the study and hence reveal the growth and development enhancing ability of natural resources and its indicators, it will be more realistic to commence with the improvement in the quality of the total agricultural rents, high educational enrolment, by directing domestic and foreign investment towards agricultural and industrial research and improving the culture of work.

\section{References}

ADI (2010), "African Development Indicators", World Bank, Washington.

ADI (2014), "African Development Indicators", World Bank, Washington

Ahrend R,(2002) "Speed of Reform, Initial Conditions, Political Orientation or What?Explaining Russian Regions" Economic Performance, DELTA Working Paper 2002-10

Alexeev M, Conrad R, (2010) "The Natural Resource Curse and Economic Transition", Forthcoming in Economic SystemsVol.8 (4); pp 01-21

Ben S. Bernanke, Alan S. Blinder (1992) "The Federal Funds Rate and the Channels of Monetary Transmission”, American Economic Review, Vol. 82, pp 901-921

Brunschweiler C.N, (2009) "Oil and growth in Transition Countries" Working Paper 09/108, Center of Economic Research at Swiss Federal Institute of Technology, Zurich 
Corden, W. M, and Neary, J. P. (1982). "Booming sector and de-industrialization in a small open economy", The economic journal 825-848

De Melo, Martha, CevdetDenizer, Alan Gelb and Stoyan Tenev, (1997) "Circumstance and Choice: The Role of Initial Conditions and Policies in Transition Economies", World Bank Policy Research Paper No. 1866 (December), Washington, D.C.: The World Bank.

Domar, E. (1946). "Capital Expansion, Rate of Growth, and Employment" Econometrica, 14(2), pp. 137-147.doi:10.2307/1905364. JSTOR 1905364. Engle, R.F. and C.W.J. Granger (1987), "Cointegration and error-correction: representation, estimation, and testing" Econometrica 55, 251-76.

Gylfason, T., (2001) "Natural Resources, Education, and Economic Development". European E conomic Review 45, 847-859.

Harrod, R.F. (1939). "An Essay in Dynamic Theory"'The Economic Journal, 49(193), pp. 14-33. doi:10.2307/2225181.JSTOR 2225181.

Iimi, Atsushi (2007) "Escaping from the Resource curse: Evidence from Botswana and the Rest of theWorld" IMF Staff Papers, Vol. 54, (4);PP $663-6995$

Johansen, S. (1991), "Estimation and HypothesisTesting of CointegrationVectors in Gaussian Vector Autoregressive Models" Econometrica, Vol.59, PP $1551-1580^{\circ}$

Johansen, S. (1995), "Estimation and Hypothesis Testing of CointegrationVectors in Gaussian Vector Autoregressive Models" African Journal of Economic Policyvol.16(2); p $_{1-30}$

Lucas, R. (1988), "The Mechanics of Economic Development," Journal of MonetaryEconomics, Vol.22, pp. $3-42$.
Luong P, Weinthal E, (2001) "Prelude to the Resource Curse: Explaining Oil and Gas Development Strategies in the Soviet Successor States and Beyond", Comparative Political Studies, 34 (4), $p p_{367-399}$

NAPAP (1990) "National Acid Precipitation Assessment Program”.1989 Annual Report to thePresident and Congress. Washington, DC.

NEPAD (2013). "Mobilizing Domestic Financial Resources for Implementing NEPAD National and RegionalProgrammes\& Projects" Africa looks within, NEPAD Planning and Coordinating Agency and UN EconomicCommission for Africa Final Report.

Njimanted, G. F, and Nkwetta, A. A. (2015). "TheImpact of Timber Exports on Economic Growth in Cameroon: an Econometric Investigation" Asian Journal of Economic ModellingVol.5(3);PP $2313-2884$

Rebelo, Sergio. (1991). 'Long-run Policy Analysis and Long-run Growth', Journal of Political Economy, Vol.99(3); pp ${ }_{500-521}$.

Sachs, J. D. and A. M. Warner,(1999) "The Big Push, Natural Resource Booms andGrowth". Journal of Development Economics Vol.PP ${ }_{59,43-76}$.

Sim, C. J. (1982). "A Systematic Study on the Marine Sponges from Jeju Island" Soong Jun University Essays Papers. Vol.43(12): $\mathrm{PP}_{187-210}$.

Solow, R. M., (1974),'Intergenerational Equity and Exhaustible Resources". Review ofEconomic Studies Vol.41, $P P_{2945}$.

Stiglitz, J., (1974) "Growth with Exhaustible Natural Resources: Efficient and OptimalGrowth Paths". Review of Economic Studies, Vol 41, PP ${ }_{123}$ 137 
Stokey, N. L., (1998) "Are There Limits to Growth?” International Economic ReviewVol.39(3), $P P_{1-31^{\circ}}$

World Bank (2014). "World Development Indicators"Washington D.C.: World BankData
World Bank(2007). "Doing Business Database", (Washington D.C.: World Bank) Data

Wujung, V. A, and Aziseh, F. I. (2016). “Assessing the Effect of Domestic Resource Mobilization the Economic Growth of Cameroon" The IEB International Journal Of Finance, pp 66-89
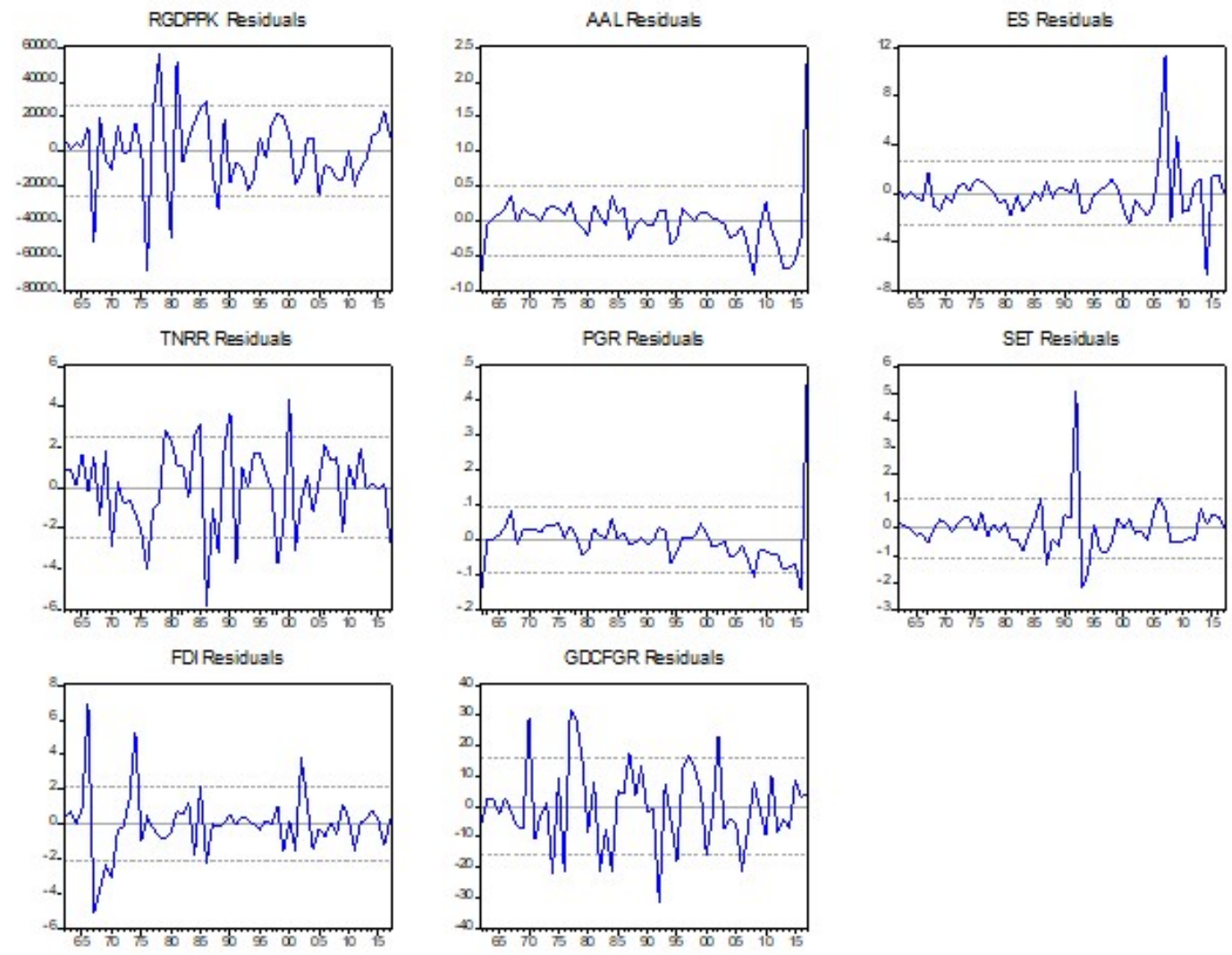